DOI:

\title{
Efektivitas Metode Problem Solving Melalui Konseling Kelompok Untuk Meningkatkan Regulasi Diri Siswa
}

\author{
Victor Gamma Kharisma \\ Bimbingan dan Konseling, Universitas Negeri Yogyakarta \\ E-mail: sevengamma@gmail.com \\ Budi Astuti \\ Bimbingan dan Konseling, Universitas Negeri Yogyakarta \\ E-mail: budi_astuti@uny.ac.id
}

\begin{abstract}
Abstrak: Tujuan dari penelitian adalah untuk mengetahui efektivitas metode problem solving melalui konseling kelompok terhadap regulasi diri siswa SMA N 1 Jatinom. Penelitian ini merupakan penelitian eksperimen dengan jenis penelitian quasi eksperimen. Desain penelitian yang digunakan Non Equivalen Pretest-Posttest. Penelitian ini menggunakan dua kelompok yaitu kelompok eksperimen sejumlah enam siswa dan kelompok kontrol sejumlah enam siswa. Populasi penelitian adalah siswa SMA N 1 Jatinom tahun ajaran 2017/2018. Teknik pengambilan sampel yang digunakan adalah purposive sampling. Proses pengumpulan data menggunakan skala regulasi diri untuk mengukur tingkat regulasi diri siswa SMA N 1 Jatinom. Efektivitas metode problem solving terhadap regulasi diri dapat dilihat dari perbedaan hasil uji wilcoxon dengan nilai sig. 0,028 lebih kecil 0,05 $(0,028<0,05)$. Perbedaan nilai rata-rata kelompok eksperimen sebesar 42,4 dan nilai rata-rata kelompok kontrol sebesar 22,2 (42,4 > 22,2). Rerata Gain Score kelompok eksperimen sebesar 0,43 sedangkan kelompok kontrol sebesar 0,23. Hasil penelitian menunjukan bahwa metode problem solving melalui konseling kelompok efektif terhadap regulasi diri siswa.
\end{abstract}

Kata Kunci: Metode Problem Solving, Regulasi Diri

\begin{abstract}
The purpose of this study was to reveal the effectiveness of problem-solving method through group counseling in improving the self-regulation of the students of SMA N 1 Jatinom. This research was experimental research with the quasi-experimental research type. The research design used the non-equivalent pretest-posttest design. This research used two groups, namely the experiment group consisting of six students and the control group consisting of six students. The research population was the students of SMA N 1 Jatinom registered in the academic year of 2017/2018. The sampling technique used was the purposive sampling technique. The data were collected using the selfregulation scale to measure the self-regulation level of the students. This could be seen in the difference through Wilcoxon test result with sig value of 0.028 which was smaller than $0.05(0.028<0.05)$. The average score of the experimental group was 42.4 and that of the control group was $22.2(42.4>22.2)$. The average gain score of the experimental group was 0.43 while that of the control group was 0.23 . The results showed that the problem-solving method through group counseling was effective in self-regulating the students.
\end{abstract}

Keywords: Problem Solving Method, Self Regulation. 


\section{PENDAHULUAN}

Perkembangan pribadi dan sosial siswa merupakan tugas dan tanggungjawab dari guru bimbingan dan konseling melalui pemberian layanan bimbingan dan konseling. Proses perkembangan pribadi dan sosial siswa membutuhkan salah satu layanan bimbingan yang penting yaitu layanan pribadi dan sosial. Pengalaman peneliti bertugas menjadi guru bimbingan dan konseling di SMA Negeri 1 Jatinom menunjukan bahwa masih banyak siswa datang kepada guru bimbingan dan konseling pada saat kelas dua belas untuk penjurusan ke perguruan tinggi negeri, tetapi pada saat kelas sepuluh dan sebelas banyak siswa tidak ingin berkonsultasi dengan guru bimbingan dan konseling. Siswa enggan bertemu dengan guru bimbingan dan konseling, karena siswa berpikir bahwa melanggar aturan pasti berurusan dengan guru bimbingan dan konseling padahal seharusnya masalah melanggar aturan bersangkutan dengan bagian kesiswaan atau wakasek kesiswaan. Kondisi yang dialami oleh Guru bimbingan dan konseling di SMA Negeri 1 Jatinom tersebut harus bekerja keras. Guru bimbingan dan konseling perlu membantu siswa untuk mengoptimalkan kemampuan aspek pribadi dan sosialnya. Guru bimbingan dan konseling di sekolah membantu mengatasi permasalahan pribadi dan sosial siswa.

Permasalahan pribadi dan sosial sering dialami oleh siswa. Salah satu permasalahan pribadi dan sosial siswa di SMA Negeri 1 Jatinom Klaten adalah rendahnya regulasi diri. Berdasarkan observasi pada tanggal 15 Agustus 2016 di SMA Negeri 1 Jatinom Klaten, siswa memiliki regulasi diri yang kurang, seperti siswa sering terlambat masuk sekolah karena sering tidur malam-malam (begadang), prestasi siswa turun dikarenakan tidak dapat mengatur belajar. Hasil wawancara dengan guru bimbingan dan konseling, banyak siswa yang memiliki regulasi diri yang kurang seperti, siswa tidak dapat berpakaian rapi.

Siswa SMA cenderung belum mempunyai regulasi diri dalam hal menjaga perilakunya, emosinya dan cara berpikir. Siswa pada masamasa Sekolah Menengah Atas masih memiliki ketidakstabilan dalam emosi, perilaku, dan berpikir. Regulasi Diri didefinisikan sebagai kemampuan untuk mengumpulkan keinginan, atau perilaku untuk mencapai tujuan jangka panjang, bahkan dengan mengorbankan tindakan jangka pendek serta mengikuti norma-norma dan aturan yang ditentukan secara sosial (Baumeister dan Vohs, 2011: 65). Siswa SMA Negeri 1 Jatinom Klaten masih belum memahami cara mengatur dirinya untuk tujuan yang tepat, seperti siswa dalam menghadapi masalah belum dapat mengatur dirinya dengan baik dan benar misalkan perilaku, emosi dan berpikirnya. Siswa dalam bertindak belum dapat menentukan tujuan. Oleh sebab itu melalui layanan bimbingan dan konseling dengan menggunakan metode problem solving melalui konseling kelompok dapat membantu siswa dalam mengatur dirinya dengan tepat.

Metode problem solving adalah suatu pendekatan untuk membantu konseli menyelesaikan permasalahan. Metode problem solving dapat diterapkan pada anak-anak, remaja, dewasa, dan lain-lain. pemecahan masalah adalah keterampilan perilaku kognitif yang diarahkan pada tujuan dan kemampuan pemecahan masalah tanpa keraguan untuk mengatasi masalah (Eskin 2013: 15). Metode problem solving mempunyai tahap-tahap dalam penyelesaian masalah konseli.

Metode problem solving mempunyai tiga sampai empat tahap dalam proses pelaksanaan problem solving. Tahapan-tahapan tersebut merupakan proses yang harus dilalui dari awal sampai akhir. Proses tahapannya sebagai berikut, Tahap awal (mengenali masalah), Tahap operasi (mengambil tindakan untuk pemecahan masalah), dan tahap mencapai tujuan yang diinginkan (menghilangkan masalah) (Eskin, 2013: 16). Proses dilakukan dengan tepat dan tidak sembarangan karena ada tekniknya. Metode problem solving juga memiliki beberapa teknik untuk melaksanakan tahapan-tahapan tersebut untuk menyelesaikan permasalahan siswa.

Proses pelaksanaan metode problem solving ada berberapa cara seperti, individual, kelompok, video, telepon, dan internet (Nezu, dan D'zurilla, 2013: 42). Peneliti melaksanakan metode problem solving dengan cara kelompok untuk proses pelaksanaan. Penggunaan Kelompok ini ada dua jenis dari kacamata bimbingan dan konseling yaitu bimbingan kelompok dan konseling kelompok. Konseling kelompok (group counseling) memiliki pencegahan (preventif) dan tujuan perbaikan terhadap pribadi, sosial, belajar dan karier (Corey, 2012: 4). Proses pembentukan konseling kelompok dibutuhkan anggota kelompok sekitar lima atau enam siswa atau orang. Peneliti dalam 
pembentukan kelompok tersebut dapat mengamati aktivitas konseling kelompok dengan jelas.

Sejauh ini penelitian yang menggunakan metode problem solving cukup berhasil terhadap masalah-masalah yang dihadapi konseli. Data penelitian metode problem solving terdahulu dari para ahli sebagai berikut. Penelitian yang dilakukan di belanda oleh Cuijpers, Annemieke, dan Warmerdam (2010). Penelitian ini menggunakan jenis penelitian eksperimen. Tujuan penelitian ini dilakukan untuk mengetahui seberapa efektif metode problem solving dalam menurun gejala depresi terhadap konseli yang mempunyai masalah dengan membandingakan terapi kognitif behavior. Hasil yang didapatkan dari penelitian ini adalah metode problem solving dapat mengurangi gejala-gejala depresi sebesar - 0,63 dari 0,01 sedangkan kogniti behavior sebesar - 0, 62 dari 0,12. Metode problem solving efektif menurunkan gejala-gejala depresi konseli yang mempunyai masalah. Coates, Malouff, dan Rooke (2008) melakukan penelitian di Australia. Penelitian tersebut menggunakan metode problem solving dan dibuat dua kelompok, yaitu kelompok eksperimen dengan subyek 65 anggota dan kelompok kontrol 64 anggota. Tujuan penelitian ini dilaksanakan untuk mengetahui efektivitas metode problem solving terhadap individu yang mengalami tekanan (stres, depresi, dan kecemasan). Hasil dari penelitian tersebut membuktikan bahwa kelompok eksperimen yang mengalami penurunan tekanan dari 65 anggota sebesar $71 \%$ sedangkan kelompok control mengalami penurunan tekanan dari 64 anggota sebesar 41 $\%$. Hasil data penelitian tersebut membuktikan keberhasilan metode problem solving.

Penelitian berikutnya yang dilakukan di aceh oleh Bass, Poudyal, Tol, Murray.,et.al. (2012). Penelitian ini menggunakan problem solving melalui konseling kelompok terhadap korban perang. Hasil dari penelitian tidak adanya dampak metode problem solving melalui konseling kelompok untuk mengurangi depresi dan gejala kecemasan dengan data kelompok kontrol sebanyak 175 anggota (85\%) dan kelompok intervensi sejumlah 158 (74\%). Penelitian berikutnya dilakukan oleh Anderson, Goddard, dan Powell (2009). Penelitian ini meneliti tentang perasaan depresi, kecemasan terhadap kehidupan sehari-hari subyek penelitiannya ada 45 orang. Penelitian ini dibagi menjadi tiga kelompok dan setiap kelompok ada
15 orang. Tujuan dari penelitian ini untuk mengetahui dampak dari metode problem solving melalui laporan diri dan pendekatan berbasis kinerja terhadap depresi dan kecemasan yang dialami oleh individu pada kehidupan sehari-hari. Hasil penelitian ini tidak memberikan bantuan dalam mengatasi depresi dan kecemasan individu dalam menghadapi kehidupan sehari-hari dan tidak ada perbedaan setelah diberi dan sebelum dengan data perbandingan kelompok depresi dengan kelompok kontrol 12,03 dan perbandingan kelompok kecemasan dengan kelompok kontrol 11,74 semua data tersebut lebih dari 0,001 . Beberapa penelitian menunjukkan bahwa ada yang efektif dan ada juga tidak efektif dalam penggunaan metode problem solving. Jadi peneliti ingin membuktikan metode problem solving efektif terhadap regulasi diri.

Berdasarkan penjelasan latar belakang masalah tersebut dan informasi penggunaan metode problem solving, bahwa pada penelitian ini, peneliti ingin melakukan penelitian quasi eksperimen untuk mengetahui efektifitas metode problem solving melalui konseling kelompok terhadap regulasi diri pada siswa SMA Negeri 1 Jatinom Klaten.

Tujuan penelitian ini adalah untuk mengetahui efektivitas metode problem solving melalui konseling kelompok terhadap regulasi diri siswa Sekolah Menengah Atas Negeri 1 Jatinom di Kabupaten Klaten.

\section{METODE}

Penelitian ini menggunakan jenis penelitian ini adalah Quasi Eksperimen dengan menggunakan desain Non Equivalen PretestPosttest. Peneliti melakukan penelitian Quasi Eksperimen atau eksperimen semu. Tujuan penelitian quasi eksperimen adalah untuk mendapatkan informasi yang merupakan sebuah data dari eksperimen sesungguhnya dalam kondisi tidak memungkinkan untuk mengontrol atau memanipulasi semua variabel yang relevan. Pengambilan datanya melalui pretest dan posttest.

Subyek penelitian ini adalah siswa SMA Negeri 1 Jatinom. Subyek tersebut terdiri dari kelas XI IPA dan XI IPS serta X A-H dengan jumlah 574. Pengambilan populasi dan sampel diambil dari kelas X dan kelas XI IPA dan IPS sebagai data penelitian. Teknik yang digunakan oleh peneliti untuk mengambil subyek adalah teknik Purposive Sampling. 
Subyek penelitian yang diambil sejumlah 12 siswa ini dibagi menjadi dua kelompok yaitu: kelompok eksperimen yang diberikan metode problem solving oleh peneliti sedangkan kelompok kedua adalah kelompok kontrol yang diberi perlakuan oleh guru bimbingan dan konseling sekolah SMA N 1 Jatinom.

Proses pembuatan skala regulasi diri sebagai instrumen dalam pengambilan data dibutuhkan kisi-kisi (butir tes) yang sesuai dengan teori yang digunakan. Kisi-kisi penyusunan ini mengambil aspek-aspek regulasi diri yang ada dikemukakan oleh Ormord (2012: 132) yaitu: (a) pengaturan standar dan tujuan, (b) Observasi diri, (c) evaluasi diri, (d) Reaksi diri, dan (e) refleksi diri. Pengujian instrumen dilakukan di sekolahan lain yang mempunyai kondisi dengan sekolah yang dijadikan penelitian untuk mengetahui validitas dan realibilitasnya. Instrumen penelitian memiliki reliabilitas yang tinggi dan mendekati 1,00.
Hasil reliabilitas instrument penelitian ini mempunyai koefisien alpha 0,936. Proses penelitian ini menggunakan teknik pengujian hipotesis dengan Uji Wilcoxon. Tujuan peneliti menggunakan Uji Wilcoxon untuk mengetahui perbandingan antara kelompok eksperimen dan kelompok kontrol dalam kondisi sebelum diberikan perlakuan serta setelah diberikan perlakuan.

\section{HASIL DAN PEMBAHASAN}

Berdasarkan data penelitian yang sudah diambil, memberikan gambaran yang jelas terhadap kelompok eksperimen dan kelompok kontrol. Data yang disajikan pada tabel 1 . memberikan gambaran perbandingan kondisi kedua kelompok sebelum diberikan perlakuan dan setelah diberi perlakuan. Berikut data pretest dan posttest yang diambil dan disajikan pada tabel:

Tabel 1. Perbandingan Statistik Kelompok Eksperimen dengan Kelompok Kontrol

\begin{tabular}{ccccc}
\hline \multicolumn{5}{c}{ Perbandingan Kelompok Eksperimen dan Kelompok Kontrol } \\
\hline \multicolumn{5}{c}{ Kelompok } \\
\hline Nilai & Kelompok Eksperimen & Kelompok Kontrol \\
\cline { 2 - 5 } Statistik & Pretest & Posttest & Pretest & Posttest \\
Mean & 61,6 & 104 & 61,8 & 84 \\
Median & 62 & 107 & 62 & 81 \\
Modus & 55 & 107 & 60 & 78 \\
SD & 4,45 & 8,44 & 3,92 & 6,47 \\
Minimum & 55 & 93 & 56 & 78 \\
Maksimum & 67 & 115 & 67 & 93 \\
\hline
\end{tabular}

Berdasarkan data tabel 1. bahwa rerata nilai pretest dan posttest dari kelompok kontrol yang diambil oleh peneliti, menyatakan bahwa rerata nilai regulasi diri kelompok kontrol mengalami peningkatan sebesar 22,2 dari nilai awalnya 61,8 meningkat menjadi 84 . Data rerata nilai regulasi diri kelompok eksperimen terjadi peningkatan sebesar 42,4 dari nilai awalnya 61,6 meningkat menjadi 104 dapat disimpulkan bahwa kelompok eksperimen mengalami peningkatan nilai yang lebih tinggi dibandingkan kelompok kontrol.

Data diatas juga didukung dengan Uji Wilcoxon untuk mengetahui efektivitas metode problem solving terhadap regulasi diri siswa. Berikut tabel keempat tentang Uji Wilcoxon:

Tabel 2. Uji Wilcoxon

\section{Test Statistics}

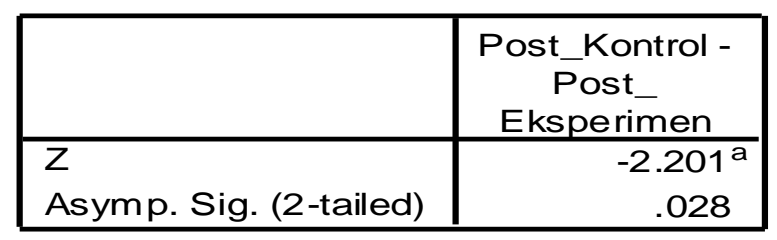

a. Based on positive ranks.

b. Wilcoxon Signed Ranks Test 
Berdasarkan hasil dari perhitungan Uji Wilcoxon pada tabel 2. Hasil yang diperoleh 0,028 dengan nilai sig $<0,05$. Hasil Hipotesis penelitian ini dapat disimpulkan bahwa Ho ditolak dan Ha diterima. Jadi berdasarkan data yang diambil dapat disimpulkan metode problem solving efektif terhadap regulasi diri siswa SMA N 1 Jatinom. Metode problem solving efektif terhadap regulasi diri siswa karena hasil Uji Wilcoxon kurang dari nilai signifikan 0,05 , tetapi berbeda bila hasil Uji Wilcoxon problem solving lebih dari nilai signifikan 0,05 berarti tidak efektif. Jadi hasil uji Wilcoxon menyatakan bahwa metode problem solving efektif terhadap regulasi diri siswa. Hasil data diatas didukung oleh penelitian yang dilakukan oleh Agustian, Firman, dan Zikra (2018) di padang tentang efektifitas metode problem solving terhadap self-regulated learning siswa. Hasil dari penelitian ini metode problem solving efektif terhadap regulasi diri dengan nilai 0.016 dengan nilai sig $<0,05$.

Proses konseling kelompok dengan menggunakan metode problem solving secara pengamatan ada kemajuan pada kelompok eksperimen, seperti anggota yang kecanduan game online android dapat mengatur dirinya agar tidak kecanduan game online android dengan cara membuat jadwal waktu bermain game online. Proses metode problem solving melalui konseling kelompok ini memberikan dampak yang signifikan terhadap anggota kelompok eksperimen sedangkan dengan kelompok kontrol yang ditangani oleh guru bimbingan dan konseling sekolah tidak mengalami perubahan yang signifikan tentang regulasi diri, karena metode yang di gunakan oleh guru bimbingan dan konseling sekolah adalah metode konvesional.

\section{SIMPULAN DAN SARAN}

Berdasarkan hasil penelitian dan pembahasan yang dilaksanakan, peneliti menyimpulkan bahwa metode problem solving melalui konseling kelompok efektif terhadap regulasi diri siswa SMA Negeri 1 Jatinom. Dampak efektifitas dari metode problem solving terlihat pada anggota kelompok eksperimen dapat mengatur dirinya dengan beberapa cara, seperti membuat jadwal unutk mengurangi kecanduan game online. Proses yang dilakukan dalam penelitian ini adalah melalui kegiatan konseling kelompok.
Regulasi diri siswa SMA Negeri 1 Jatinom ada perbedaan yang signifikan antara kelompok eksperimen dengan kelompok kontrol. Kelompok eksperimen mengalami peningkatan regulasi diri setelah diberikan perlakuan metode problem solving sedangkan kelompok kontrol yang tidak diberikan perlakuan metode problem solving tidak mengalami peningkatan. Perbedaan kelompok eksperimen dengan kelompok kontrol dapat dilihat pada hasil Uji Wilcoxon dengan nilai sig. 0,028 lebih kecil 0,05 $(0,028<0,05)$. Perbedaan nilai rata-rata kelompok eksperimen sebesar 42,4 dan nilai rata-rata kelompok kontrol sebesar 22,2 (42,4 > 22,2).

Terdapat beberapa saran yang dapat disampaikan yaitu: pertama guru bimbingan dan konseling dapat menggunakan metode problem solving untuk layanan bimbingan dan konseling di SMA Negeri 1 Jatinom. Kedua, Peneliti selanjutnya dapat menggunakan dan mengembangkan metode problem solving terhadap regulasi diri atau variabel yang lain.

\section{DAFTAR RUJUKAN}

Agustian, W.Y, Firman, \& Zikra. (2018). Efektifitas layanan penguasaan konten menggunakan metode problem solving untuk meningkatkan self regulated learning siswa. Konselor, VV (N): pp. $\mathrm{XX}-\mathrm{XX}$.

Anderson, R.J, Goddard, L., \& Powell, J.H. (2009). Social Problem-Solving Processes and Mood in College Students: An Examination of Selfreport and Performance-based Approaches. Springer Science and Business Media, LLC, 33:175-186.

Bass, J., Poudyal, B., \& Murray, L., et.al. (2012). A controlled trial of problemsolving counselling for war-affected adults in Aceh, Indonesia. Soc Psychiatry Psychiatr Epidemiol, 47:279-291

Coates, C., Malouff, J.M., \& Rooke, S.E. (2008). Efficacy of Written Modeling and Vicarious Reinforcement in Increasing Use of Problem-Solving Methods by Distressed Individuals. The Journal of Psychology, 4, 413425 . 
Corey, C., Corey, G., \& Corey, M.S. (2014). Groups: Process and Practice ( $8^{r d}$ ed.). New York: Brooks/Cole, Cengage Learning.

Cuijpers, P., Straten, A.V., \& Warmerdam, L. (2010). Online cognitive behavioral therapy and problem-solving therapy for depressive symptoms: Exploring mechanisms of change. European Psychiatry, 41, $64-70$.
D'Zurilla, T.J., Nezu, A.M. \& Nezu, C.M. (2013). Problem-Solving Therapy: a treatment manual. New York: Springer Publishing Company, LLC.

Eskin, M. (2013). Problem Solving Therapy in the Clinical Practice. London: Elsevier Inc. 